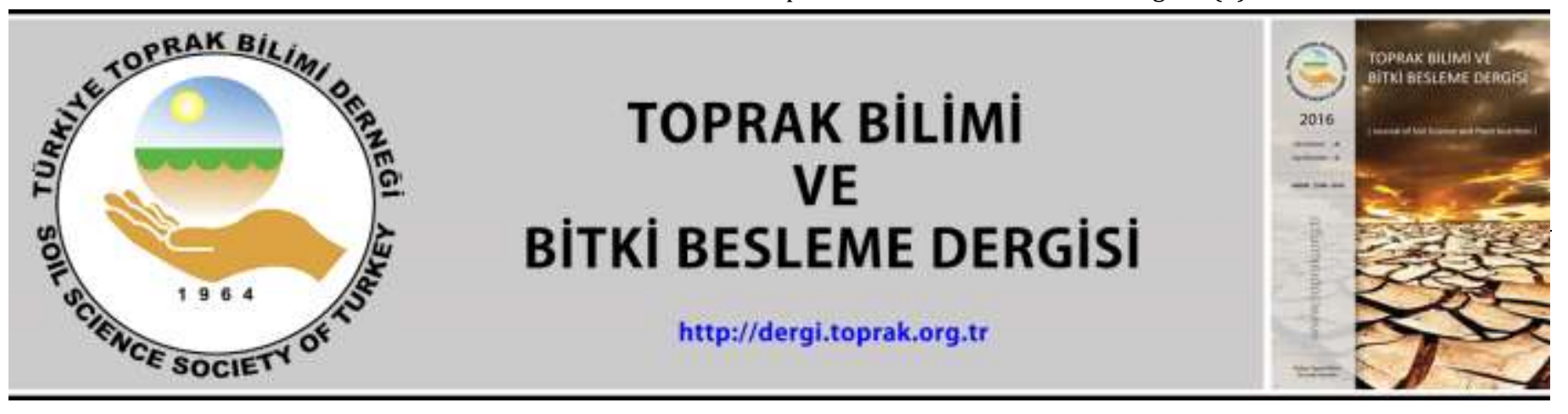

\title{
Çorlu deresi ve yakın çevresi (Çerkezköy-Çorlu hattı) topraklarının ağır metal kirliliğinin değerlendirilmesi
}

\section{Zafer Varol 1, Duygu Boyraz Erdem 2,*}

\author{
${ }^{1}$ Lotus Analiz Gıda Laboratuvar Hiz. A. S. Avcllar, İstanbul \\ ${ }^{2}$ Namık Kemal Üniversitesi, Ziraat Fakültesi, Toprak Bilimi ve Bitki Besleme Bölümü, Tekirdăg
}

\begin{abstract}
Özet
$\mathrm{Bu}$ araştırmada, Ergene Havzası drenaj ağ sisteminin önemli bir kolu olan Çorlu Deresi hattı boyunca su örnekleri için 15 örnek noktası ve toprak örnekleri için 20 örnek noktası belirlenmiş ve her örnek noktasından 3 örnek alınarak bazı fizikokimyasal ve ağır metal analizleri yapılmıştır. Su örnekleri analiz sonuçlarından $\mathrm{Na}^{+}(\mathrm{mg} / \mathrm{l})$ değerine göre sulama suyu kalitesi IV. sınıf olarak belirlenmiștir. Ayrıca, 6 örnek noktasının sulama suyu sınıfı C3-S1 olarak sınıflandırılmıștır. Ağır metal analiz sonuçları açısından değerlendirildiğinde ise; $\mathrm{Zn}, \mathrm{Cu}, \mathrm{Cr}, \mathrm{As}, \mathrm{Cd}, \mathrm{Pb}$, Ni sonuçları sırası ile 65.7-198.8; 0.6-203.8; 6.5-69.4; 1.2-22.3; 0.1-0.3; 0.3-8.4; 9.3-57 $\mu \mathrm{g} / \mathrm{l}$ aralıklarında ölçülmüş olup herhangi bir sorun gözlenmemiştir. Fe ve Mn elementlerinin analiz sonuçlarına ilişkin değerler sırayla; 587-8969.7 ve 120.5-329.7 $\mu \mathrm{g} / \mathrm{l}$ aralıklarında belirlenmiș olup, Fe elementinde 2 örnekleme noktalarında sinır değerlerini aştığı gözlenmiştir. Ayrıca, toprak örneklerinin ağır metal analiz sonuçları incelendiğinde $\mathrm{Cu}, \mathrm{Zn}, \mathrm{Pb}, \mathrm{Cd}, \mathrm{Ni}, \mathrm{Cr}, \mathrm{Hg}, \mathrm{Sn}, \mathrm{Co}$ ve $\mathrm{As}$ değerleri sırasıyla 3-20; 7-53; 14.8- 24.4; 0-0.1; 4.1-28.8; 9-200.9; 0.1-0.3; 0.3-2.5; 1.8-8.1; 0.7-3 mg/kg arasında değișmiștir. Bu sonuçların, Cevre ve Orman Bakanlığı Toprak Kirliliği Kontrolü Yönetmeliğine göre yapılan değerlendirmede izin verilen sınır değerlerinin altında olduğu tespit edilmiştir. Ba elementi analiz sonuçları ise $135.5-389.7 \mathrm{mg} / \mathrm{kg}$ olarak ölçülmüş ve izin verilen sınır değerlerinin üstünde sonuç verdiği görülmesine karşın, fizikokimyasal analiz sonuçlarına göre ise yapılan değerlendirme de ciddi bir sorun belirlenmemiştir. Araştırma sonuçlarına göre; Ergene havzasının iyi nitelikli ve verimli topraklarının ve bu havzayı besleyen su kaynaklarının çevre kirliliğine maruz kalmaması için Çevre ve Orman Bakanlığı Su Kirliliği Kontrolü Yönetmeliği ve Toprak Kirliliği Kontrolü Yönetmeliği' ne uygun hareket edilmesi gerekmektedir. Ayrıca ıslah çalışmalarının aksamadan devam edilmesi ve gerekli kontrollerin yapılması için özen gösterilmelidir.

Anahtar Kelimeler: Çorlu Deresi, ağır metal, su kirliliği, toprak kirliliği.
\end{abstract}

\section{Evaluation of heavy metal pollution of Çorlu stream and the near surronding soils (Çerkezköy-Çorlu line)}

\begin{abstract}
In this study, 15 points for water samples and 20 points for soil samples were determined along the Corlu Stream, which is an important branch of the Ergene Basin drainage network system, and some physicochemical and heavy metal analyses were performed by taking 3 samples from each point. According to $\mathrm{Na}^{+}(\mathrm{mg} / \mathrm{l})$ value from water samples analysis, irrigation water quality class was determined as IV. class. In addition, irrigation water class of 6 sample points is classified as C3-S1 class. When evaluated in terms of heavy metal analysis results; $\mathrm{Zn}, \mathrm{Cu}, \mathrm{Cr}, \mathrm{As}, \mathrm{Cd}, \mathrm{Pb}$, Ni results as range of 65.7-198.8; 0.6-203.8; 6.5-69.4; 1.2-22.3; 0.1-0.3; 0.3-8.4; 9.3-57 $\mu \mathrm{g} / \mathrm{l}$ was measured and no problems were observed in the evaluation. The analysis results of Fe and Mn elements was determined in the ranges of 587-8969.7 and 120.5-329.7 $\mu \mathrm{g} / \mathrm{l}$ and it was observed that the Fe element exceeded the limit values at 2 points. According to heavy metal analysis results, $\mathrm{Cu}, \mathrm{Zn}, \mathrm{Pb}, \mathrm{Cd}, \mathrm{Ni}, \mathrm{Cr}, \mathrm{Hg}$, $\mathrm{Sn}$, Co and As values ranged from 3-20; 7-53; 14.8- $24.4 ; 0$ to $0.1 ; 4.1$ to $28.8 ; 9$ to $200.9 ; 0.1-0.3 ; 0.3-2.5 ; 1.8-8.10 .7-3 \mathrm{mg} / \mathrm{kg}$, respectively. It has been determined that these results are below the permitted limit values according to the Regulation on Soil Pollution Control of the Ministry of Environment and Forestry. Ba element analysis results were measured as $135.5-389.7 \mathrm{mg} / \mathrm{kg}$ and although it was seen to give results above the permitted limit values, no serious problem was determined according to the results of physicochemical analysis. According to the research results; It is necessary to act in accordance with the Water Pollution Control Regulation and the Soil Pollution Control Regulation of Ministry of Environment and Forestry in order to prevent the well-qualified and fertile soils of the Ergene basin and the water resources feeding this basin from being exposed to environmental pollution. In addition, breeding activities should be taken to continue the improvement works without delay and to make the necessary controls.
\end{abstract}

Keywords: Çorlu stream, heavy metal, water pollution, soil pollution.

(C) 2020 Türkiye Toprak Bilimi Derneği. Her Hakkı Saklıdır

\footnotetext{
* Sorumlu yazar:

Tel. : $\quad 05309314547$

E-posta : dboyraz@nku.edu.tr

Geliș Tarihi

Kabul Tarihi

04 Nisan 2020

16 Haziran 2020

e-ISSN

DOI

2146-8141

$10.33409 /$ tbbbd.756996
} 


\section{Giriş}

Son yıllarda hızla artan ve büyük problemler oluşturan su kaynaklarının ve toprakların ağır metal açısından kirlenmesi istenilen boyutta incelenmemiștir. Çağımızda doğayı, ekosistemi, insan ve hayvan sağlığını tehdit eden en önemli tehlikelerin başında çevre kirliliği gelmektedir. Dünya nüfusunun hızla artması, hızla gelişen endüstrilerin ve daha medeni yaşama düzeyi sağlama amacı ile gösterilen çabaların istenmeyen sonucu olarak çevre kirliliği ortaya çıkmakta ve günümüzde de giderek artan boyutlarda önemini korumaktadır (Baş ve ark., 1992).

Ülkemizin en büyük sanayi merkezleri olan İstanbul ve Kocaeli illerinde yer kalmaması ve bu bölgelerin yükü kaldıramaması sebebiyle 1973 yılında alınan karar ile Çorlu-Çerkezköy'de yeni Organize Sanayi Bölgesi'nin (OSB) kurulmasına bașlanmıștır. Fakat bu OSB'deki sanayi kuruluşları işletme sularını yakın zamana kadar Ergene Nehri'nin bir kolu olan Çorlu Deresi'ne bırakmışlardır.

Çorlu Deresinin, Çerkezköy ve Marmaracık arasında bulunan kısım kirlenmenin en çok görüldüğü bölgelerdir. $\mathrm{Bu}$ nedenle özellikle bu bölgede sulama suyu ve toprakta oluşan ağır metal kirlenmesinin incelenmesine gerek duyulmaktadır. Ergene Havzasında yapılmış olan birçok araştırma da ağır metal kirliliğin boyutları ortaya konulmuştur.

Güneş ve ark (2001) tarafından Ergene Nehri'ni oluşturan en önemli kollardan biri olan Çorlu Deresi üzerinde seçilen 8 örnekleme noktasından su örnekleri alınmış ve $\mathrm{Zn}, \mathrm{Pb}, \mathrm{Fe}$ ve $\mathrm{Cu}$ analizleri yapılmıştır. Araştırıcılar söz konusu bu elementlere ilişkin değerleri sırayla; 0.169-0.349; 0.096- 0.352; 0.896-3.68 ve 0.244-1.63 mg/l arasında belirlemişlerdir. Bu araştırma sonucunda Çorlu Deresi suyunda önemli ölçüde Pb ve Fe kirliliğinin olduğunu ortaya çıkarmıştır.

Kocaman ve ark (2011) Ergene Nehri'nden yaptıkları başka bir çalışmaya göre sulama suyu açısından uygun olmayan sular ile yapılan sulamadan dolayı kaliteli toprakların kirlendiği, bu şekilde devam edilirse çok kısa sürede Ergene Nehri kenarındaki tarım arazilerinin çölleşeceğini belirlemiştir. Bu durum hem ekolojik hem de bölge halkında ekonomik ve sosyolojik sorunları ortaya çıkarmıştır.

Ergene havzasında belirlenen 17 kuyudan alınan yeraltı sularında aylık periyotlar ile $\mathrm{Fe}, \mathrm{Zn}, \mathrm{Mn}, \mathrm{Cr}, \mathrm{Cd}, \mathrm{Pb}$ analizleri yapılmış ve kirlilik durumu ortaya çıkarılmıştır. Yapılan araştırmalar sonucunda inceleme alanının Çorlu- Vakıflar (GB) kesiminde yeraltı sularındaki $\mathrm{Cr}$, Cd ve Pb konsantrasyonlarının yıllık ortalamalarının sirasıyla $0.65 \mathrm{mg} / \mathrm{l}-0.04 \mathrm{mg} / \mathrm{l}$ ve $0.23 \mathrm{mg} / \mathrm{l}$ olduğu ve bu değerlerin WHO, EPA ve TSE nin sinır değerlerini aştığı görülmüştür. Bu ağır metallerin değerlerdeki artışın muhtemel nedeni olarak çalışma alanında yer alan deri, tekstil ve diğer sanayi kuruluşlarının ağır metal içerikli işletme sularının akifere karışması olarak gösterilmektedir (Arkoç, 2012).

Ergene Nehri Uzunköprü istasyonunda alınan su örneklerinde ağır metal kirliliği incelenmiş, Cd konsantrasyonu bakımından ise III. sınıf, $\mathrm{Pb}$ ve $\mathrm{Cu}$ konsantrasyonu bakımından ise IV. sınıf bir sulama suyu olduğu belirlenmiştir. Ergene nehrindeki bu denli yüksek ağır metal kirliliğin sebebi olarak Çorlu ve Çerkezköy bölgesinde yoğunlaşan organize sanayi bölgelerinin artması, evsel ve endüstriyel atık suların hiçbir ön arıtmaya tabi tutulmadan Ergene Nehri'ne boşaltılması gösterilmiştir (Anonim, 2003).

Meriç Nehri'nde yapılan bir araştırmaya göre, nehirde önemli miktarlarda ağır metaller tespit edilmiştir. Meriç Nehrinin Kapıkule istasyonundan alınan su numunelerinde $\mathrm{Pb}$ ve $\mathrm{Cu}$ 'ın değerlerinin izin verilebilir sınır değerlerin çok üzerinde olduğu görülmüştür. Bu araştırma sonucunda Meriç Nehri'nin su kalite sınıfı Pb ve $\mathrm{Cu}$ açısından IV. sınıf olarak tespit edilmiştir (Anonim, 2003).

Eyüpoğlu ve ark. (1996), tarafından Türkiye'nin değişik bölgelerinden toplam 1511 toprak örneği alınmış ve araştırmalar yapılmıştır. Bu araştırma sonuçlarına göre Türkiye topraklarının yaklaşık \% 27'sinde yarayışlı Fe miktarı orta düzeyde ve \% 73'ünde ise yüksek düzeylerde olduğu tespit edilmiştir.

Cvetkovic ve ark. (2006) yapmış oldukları araştırmada kadmiyumun az kirlenmiş topraklarda 0.2-0.6 mg/kg arasında olduğunu, aşırı kirlenmiş topraklarda ise $800 \mathrm{mg} / \mathrm{kg}^{\prime}$ a kadar ulaşılabildiğini tespit etmişlerdir.

İnsanlar için günlük krom alım miktarı 30-200 $\mu g^{\prime}$ dır. Bu oranda alınan krom miktarı toksik etki göstermez. $\mathrm{Cr}$ vücutta insülin hareketini sağlayarak karbonhidrat, su ve protein metabolizmasını etkilemektedir. Kirlenmemiş suda ortalama $\mathrm{Cr}$ değeri $1 \mu \mathrm{g} / \mathrm{l}$ olarak bulunur. Bir çok toprakta az miktarda krom (2-60 $\mathrm{mg} / \mathrm{kg}$ ) bulunurken, bazı topraklarda bu değer $4 \mathrm{~g} / \mathrm{kg}$ kadar çıkmaktadır (Mertz, 1987).

Gerendas ve ark. (1999) yapmış oldukları bir araştırmada toprakta bulunan nikelin ekstrakte edilebilir değerini $10 \mathrm{mg} / \mathrm{kg}$ olarak tespit etmişlerdir.

Bu çalışma ile OSB'nin, küçük sanayi kuruluşlarının bıraktı̆̆ı atıkların ve diğer ağır metal kaynaklarının Çorlu Deresi'nde ve bölge toprağında meydana getirdiği ağır metal kirlenmesinin boyutunu ve yapılan ıslah 
çalışmalarının ne kadar başarılı olduğunun ortaya konması amaçlanmıştır. Elde edilen veriler değerlendirilerek ağır metal kirliliğinin insan ve çevre üzerine olan olumsuz etkilerini azaltmak amacıyla yapılacak çalışmalara kaynak oluşturması sağlanmış olacaktır.

\section{Materyal ve Yöntem}

\section{Örneklerin Alındığı Bölgenin Coğrafi Konumu}

Çorlu Deresi Çerkezköy'ün doğusunda bulunan Istıranca Dağlarından doğmaktadır. Paşa Deresini de içine alarak kuzeydoğu-güneybatı yönünde akmaktadır. Çorlu Deresi Çorlu İlçe merkezinin 5 km kuzeyinden geçtikten sonra, Marmaracık ve Kütüklü Derelerini içine almaktadır. Muratlı İlçesinin kuzeyinde Ergene Nehri'ne karışmaktadır. Sanayinin yoğun olduğu Çerkezköy'de 200'den fazla fabrikanın \%65'ini oluşturan tekstil fabrikalarının boya atıkları Kayak Dereye, oradan da Çorlu Deresi ile birleșerek Ergene Nehrine ulaşmaktadır. Ergene Nehri ise İpsala yakınlarında Meriç Nehri ile birleşerek Saroz körfezinden Ege Denizine akmaktadır (Tan 2006).

Çorlu Deresi, Çerkezköy'ün doğusundan doğarak Boyacıçatağı, Lefka ve Paşa Deresi ile birleşip Çerkezköy'e ulaşmaktadır. Çorlu'nun kuzeyinden geçtikten sonra Marmaracık ve Kütüklü Derelerini içerisine almakta ve Muratlı'nın kuzeyinden Ergene'ye karışmaktadır. Su toplama havzası 1.319 km², uzunluğu 62 km'dir (www.cerkezkoy.bel.tr (erişim tarihi, 10.07.2014)).

\section{Materyal}

Çorlu Deresinin Çerkezköy-Çorlu istikametinden geçmekte olan yaklaşık $34.5 \mathrm{~km}$ 'lik hat üzerinden su örnekleri için 15 örnek noktası, toprak örnekleri için 20 örnek noktası belirlenmiştir. Her bir örnek noktasından su ve toprak örneklerinden 3 adet örnek olmak üzere toplam 45 adet su örneği ve 60 adet toprak örneği alınarak analiz edilmiştir.

Örneklerin alınmasına Çerkezköy-Çorlu istikametine göre başlanmıştır. Alınan örneklerin ilk 6 örnek noktası Çerkezköy, geriye kalan 9 örnek noktası ise Çorlu sınırları içinde yer almaktadır. Bu örnek noktalarının belirlenmesinde özellikle sanayi kuruluşlarının yoğun bulunduğu yerlerin seçilmesine özen gösterilmeye çalışılmıştır. Böylece analiz sonuçlarındaki değişim gözlemlenerek sanayi kuruşlarının etkisi net bir şekilde ortaya konmuştur. Su ve toprak örneklerinin alındığı noktaların koordinatları GPS yardımıyla belirlenmiş ve Google Earth görüntüsüne işaretlenerek Şekil 1'de verilmiştir.

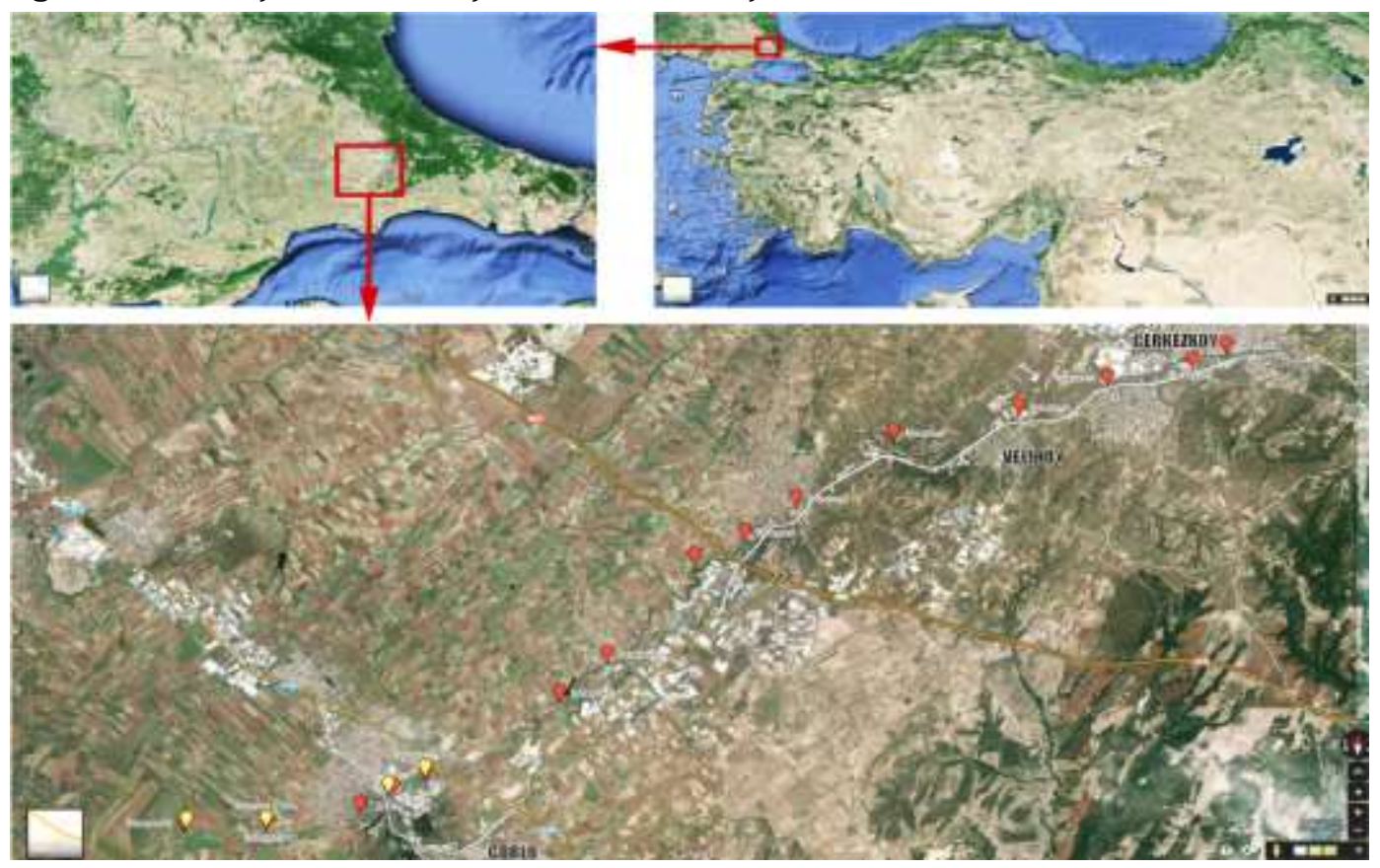

Şekil 1. Su ve toprak örneklerinin toplandığı noktaların Google Earth görüntüsü

\section{Metot}

Alınan toprak örneklerinde; toprak reaksiyonu, 1:2.5 toprak-su süspansiyonunda pH metre ile ölçülmüştür (Sağlam 2008). Kireç analizi, Scheibler Kalsimetresi ile Anonim (1996a) yöntemine göre, tuz Anonim (1996b), ağır metal analizleri, Anonim (2004a) (ICP MS) standardına göre belirlenmiştir. Tekstür tayini, Bouyoucos (1951) hidrometre yöntemine göre belirlenmiştir. 
Su örneklerinde pH analizi, Anonim (2013) standardına göre, EC analizi, Anonim (1996c) standardına göre, $\mathrm{CO}_{3}-\mathrm{HCO}_{3}$ analizi, $\mathrm{H}_{2} \mathrm{SO}_{4}$ ile titrasyon yöntemiyle (Sağlam, 2008), SAR analizi, Anonim (2009) standardına göre, ESP, SAR değerinden yararlanılarak hesaplanmıștır (Richards,1954). Sulama suyu sınıflandırması, Anonim (2009) standardına göre yapılmıştır. Su örneklerinde RSC, $\left(\mathrm{CO}_{3}^{-2}+\mathrm{HCO}_{3}{ }^{-1}\right)$ den $\left(\mathrm{Ca}^{+2}+\mathrm{Mg}^{+2}\right)$ iyonları farkından hesaplanmıştır (Eaton, 1950).

Su ve toprak örnekleri arasındaki korelasyon ise Yurtsever (1984) 'de verilen esaslara göre IBM SPSS Statistics 23 paket programı ile yapılmıştır.

\section{Bulgular ve Tartışma}

\section{Su Örneklerinin Sulama Suyu Kriterleri Açısından Değerlendirilmesi}

Çorlu Deresinden alınan su örneklerinin değerlendirilmesinde Çizelge 1'de verilen sulama suyu sınır değerleri kullanılmıştır (Anonim, 2004b). Çorlu Deresinin 15 farklı noktasından alınan su örneklerinin sonuçları ise Çizelge 2'de verilmiştir.

Çizelge 1. Sulama suyu sınıflandırılmasında esas alınan sulama suyu kriterleri (Anonim, 2004b).

\begin{tabular}{|c|c|c|c|c|c|}
\hline \multirow[b]{2}{*}{ Kalite kriterleri } & \multirow[b]{2}{*}{ I. Sinif } & \multicolumn{4}{|c|}{ SULAMA SUYU SINIFI } \\
\hline & & II. Sinif & III. Sinıf & IV. Sinif & V. Sinif \\
\hline $\mathrm{EC}_{25} \times 10^{6}$ & $0-250$ & $250-750$ & $750-2000$ & $2000-3000$ & $>3000$ \\
\hline $\mathrm{pH}$ & $6.5-8.5$ & $6.5-8.5$ & $6.5-8.5$ & $6-9$ & $<6,>9$ \\
\hline Değișebilir Sodyum Yüzdesi (\% Na) & $<20$ & $20-40$ & $40-60$ & $60-80$ & $>80$ \\
\hline Sodyum $\left(\mathrm{mg} \mathrm{Na}^{+} / \mathrm{l}\right)$ & 125 & 125 & 250 & $>250$ & $>250$ \\
\hline Sodyum Adsorbsiyon oranı (SAR) & $<10$ & $10-18$ & $18-26$ & $>26$ & \\
\hline Sodyum karbonat kalıntısı (RSC) me/l & $<1.25$ & $1.25-2.5$ & $>2.5$ & & \\
\hline Sulama suyu sinıfı & $\mathrm{C}_{1} \mathrm{~S}_{1}$ & $\begin{array}{l}\mathrm{C}_{1} \mathrm{~S}_{2} \\
\mathrm{C}_{2} \mathrm{~S}_{2} \\
\mathrm{C}_{2} \mathrm{~S}_{1}\end{array}$ & $\begin{array}{c}\mathrm{C}_{1} \mathrm{~S}_{3}, \mathrm{C}_{2} \mathrm{~S}_{3}, \\
\mathrm{C}_{3} \mathrm{~S}_{3}, \mathrm{C}_{3} \mathrm{~S}_{2}, \\
\mathrm{C}_{3} \mathrm{~S}_{1}\end{array}$ & $\begin{array}{l}\mathrm{C}_{1} \mathrm{~S}_{4}, \mathrm{C}_{3} \mathrm{~S}_{4}, \\
\mathrm{C}_{4} \mathrm{~S}_{3}, \mathrm{C}_{4} \mathrm{~S}_{1}\end{array}$ & $\begin{array}{l}\mathrm{C}_{2} \mathrm{~S}_{4}, \\
\mathrm{C}_{4} \mathrm{~S}_{4}, \\
\mathrm{C}_{4} \mathrm{~S}_{2},\end{array}$ \\
\hline
\end{tabular}

Çizelge 2. Sulama suyu sınıflandırılmasında esas alınan bazı sulama suyu analiz sonuçları

\begin{tabular}{|c|c|c|c|c|c|c|c|c|c|c|c|c|c|}
\hline$* 1$ & 2 & 3 & 4 & 5 & 6 & 7 & 8 & 9 & 10 & 11 & 12 & 13 & 14 \\
\hline 1. & 7.7 & 161 & 55 & 2.4 & 4.0 & 0.2 & 36 & 0.0 & 3.0 & $<0.0$ & 1.2 & 1.7 & C1-S1 \\
\hline 2. & 7.3 & 147 & 52 & 2.2 & 3.9 & 0.2 & 35 & 0.0 & 4.1 & 0.2 & 1.1 & 1.6 & C1-S1 \\
\hline 3. & 7.1 & 736 & 384 & 16.7 & 19.6 & 0.2 & 46 & 0.0 & 4.5 & $<0.0$ & 6.1 & 5.3 & C2-S1 \\
\hline 4. & 7.1 & 320 & 133 & 5.8 & 8.9 & 0.2 & 39 & 0.0 & 5.5 & $<0.0$ & 2.6 & 2.7 & C2-S1 \\
\hline 5. & 7.3 & 787 & 532 & 23.7 & 26.4 & 0.4 & 47 & 0.8 & 9.4 & $<0.0$ & 7.6 & 6.5 & C3-S1 \\
\hline 6. & 7.7 & 800 & 530 & 22.8 & 25.6 & 0.4 & 47 & 0.8 & 10.1 & $<0.0$ & 7.4 & 6.4 & C3-S1 \\
\hline 7. & 7.5 & 944 & 499 & 21.1 & 23.7 & 0.4 & 47 & 0.8 & 9.2 & $<0.0$ & 7.1 & 6.1 & C3-S1 \\
\hline 8. & 7.8 & 802 & 481 & 21.2 & 24.0 & 0.4 & 46 & 1.6 & 8.4 & $<0.0$ & 7.1 & 6.1 & C3-S1 \\
\hline 9. & 7.6 & 801 & 499 & 21.5 & 24.8 & 0.5 & 46 & 1.6 & 8.2 & $<0.0$ & 7.0 & 6.1 & C3-S1 \\
\hline 10. & 7.8 & 772 & 487 & 19.2 & 22.4 & 0.5 & 46 & 1.9 & 7.9 & $<0.0$ & 6.6 & 5.7 & C3-S1 \\
\hline 11. & 7.9 & 701 & 366 & 16.7 & 18.9 & 0.3 & 47 & 1.6 & 8.4 & $<0.0$ & 6.2 & 5.4 & C2-S1 \\
\hline 12. & 7.9 & 686 & 400 & 17.1 & 20.0 & 0.3 & 46 & 1.6 & 8.9 & $<0.0$ & 6.2 & 5.4 & C2-S1 \\
\hline 13. & 7.8 & 648 & 369 & 15.8 & 18.2 & 0.3 & 46 & 1.6 & 8.6 & $<0.0$ & 6.0 & 5.2 & C2-S1 \\
\hline 14. & 7.8 & 715 & 370 & 15.8 & 18.4 & 0.3 & 46 & 1.6 & 9.1 & $<0.0$ & 5.9 & 5.2 & $\mathrm{C} 2-\mathrm{S} 1$ \\
\hline 15. & 7.9 & 658 & 359 & 15.5 & 17.9 & 0.3 & 46 & 1.6 & 8.6 & $<0.0$ & 5.9 & 5.2 & $\mathrm{C} 2-\mathrm{S} 1$ \\
\hline Mak. & 7.9 & 944 & 532 & 23.7 & 26.4 & 0.5 & 47 & 1.9 & 10.1 & 0.2 & 7.6 & 6.5 & \\
\hline Min. & 7.1 & 147 & 52 & 2.2 & 3.9 & 0.2 & 35 & 0 & 3 & $<0.0$ & 1.1 & 1.6 & \\
\hline Ort. & 7.6 & 645.2 & 367.7 & 15.8 & 18.4 & 0.3 & 44.4 & 1.0 & 7.6 & 0.2 & 5.6 & 5.0 & \\
\hline
\end{tabular}

*1)İstasyonlar; 2) pH; 3) EC ( $\mu$ mhos.cm-1); 4) Na (mg/l ); $\left.\left.\left.\left.5 \mathrm{Na}^{+}(\mathrm{me} / \mathrm{l}) ; 6\right) \mathrm{Ca}^{2+}+\mathrm{Mg}^{2+}(\mathrm{me} / \mathrm{l}) ; 7\right) \mathrm{K}^{+}(\mathrm{me} / \mathrm{l}) ; 8\right) \mathrm{Na}^{+}(\%) ; 9\right)$ $\mathrm{CO}_{3}^{-2}(\mathrm{me} / \mathrm{l}) ; 10$ ) $\left.\left.\mathrm{HCO}_{3}^{-3}(\mathrm{me} / \mathrm{l}) ; 11\right) \mathrm{RSC}(\mathrm{me} / \mathrm{l}) ; 12\right) \mathrm{ESP}$; 13) SAR; 14) Sulama suyu sinıfi

Çizelge 2'de verilen su örnekleri analiz sonuçları değerlendirildiğinde: Çizelge 1'de verilen Su Kirliliği Kontrolü Yönetmeliğine göre $\mathrm{pH}, \mathrm{EC}, \% \mathrm{Na}^{+}, \mathrm{Ca}^{2+}+\mathrm{Mg}^{2+}, \mathrm{K}^{+}, \mathrm{CO}_{3}^{-2}, \mathrm{HCO}_{-3}^{-}$, RSC, ESP ve SAR değerlerinde sulama suyu kullanımı açısından herhangi bir sorun olmadığı belirlenmiştir. Fakat $\mathrm{Na}^{+}(\mathrm{mg} / \mathrm{l})$ açısından örneklerin $52 \mathrm{mg} / \mathrm{l}$ ile $532 \mathrm{mg} / \mathrm{l}$ arasında değiștiği, 3, 5, 6, 7, 8, 9, 10, 11, 12, 13, 14, 15 nolu örneklerin IV. sınıf su olduğu belirlenmiştir. $\mathrm{Na}^{+}$açısından en düşük değer $(52 \mathrm{mg} / \mathrm{l})$ olan 2 nolu örnek ile en yüksek değer olan (532 mg/l) 5 nolu örnek arasında yaklaşık olarak 10 katı kadar arttığı ve bu durumun çok sıkıntılı sonuçlar oluşturacağı görülmektedir. DSİ XI. Bölge Müdürlüğü'nün 1965-1990 yılları arasında Lüleburgaz İstasyonunda ölçülen aylık toplam akımlar ve ortalama değerler verilerine göre de artış gösterdiği belirlenmiștir (Anonim, 2010b). 
Sulama suyu sınıfı olarak sanayi bölgesinin nispeten az olduğu 1 ve 2 nolu örnek noktasında C1-S1, 3 ve 4 nolu örnek noktasında C2-S1 olduğu, daha sonra sanayileșmenin artması ile sulama sınıfının 5, 6, 7, 8, 9 ve 10 nolu örnek noktalarının C3-S1, daha sonra 11 nolu örnek noktasından sonra sanayi bölgelerinden uzaklaştıkça tekrar C2-S1 sınıfında olduğu belirlenmiştir. Sulama suyu sınıfı olarak yapılan değerlendirmede genel olarak Çorlu Deresinde C3-S1 sınıfında III. sınıf su kategorisinde olduğu ve sulama suyu olarak kullanılırken dikkatli olunması gerektiği ortaya çıkmaktadır.

\section{Su örneklerinin ağır metal içeriklerinin değerlendirilmesi}

Su örneklerinde yapılan ağır metal analiz sonuçları Çizelge 3'de verilen "Sulama Sularında İzin Verilebilen Maksimum Ağır Metal ve Toksik Elementlerin Konsantrasyonların her türlü zeminde sürekli sulama yapıldığı durumda sınır değerler" (Anonim, 2004b) ve Çizelge 4'de verilen "Kıta İçi Su Kaynaklarının Sınıflarına Göre Kalite Kriteri” (Anonim, 2015)'ne göre değerlendirilmiştir. Çorlu Deresinden alınan su örneklerinin ağır metal (Fe, $\mathrm{Mn}, \mathrm{Zn}, \mathrm{Ba}, \mathrm{Cu}, \mathrm{Cr}, \mathrm{Ni}, \mathrm{Co}, \mathrm{As}, \mathrm{Pb}, \mathrm{Cd}$ ve $\mathrm{Hg}$ ) analiz sonuçları Çizelge $5^{\prime}$ de verilmiştir.

Çizelge 3. Sulama sularında izin verilebilen maksimum ağır metal ve toksik elementlerin konsantrasyonları (Anonim, 2004b).

\begin{tabular}{|c|c|c|}
\hline \multicolumn{3}{|c|}{ İzin Verilen Maksimum Konsantrasyonlar } \\
\hline Elementler & $\begin{array}{l}\text { Her türlü zeminde sürekli sulama } \\
\text { yapıldığı durumda sınır değerler (mg/kg) }\end{array}$ & $\begin{array}{l}\text { pH değeri 6,0-8,5 arasında olan killi zeminlerde } \\
24 \text { yıldan daha az sulama yapıldığında (mg/l) }\end{array}$ \\
\hline Arsenik (As) & 0,1 & 2 \\
\hline Kadmiyum (Cd) & 0,01 & 0,05 \\
\hline Krom (Cr) & 0,1 & 1 \\
\hline Kobalt (Co) & 0,05 & 5 \\
\hline Bakır (Cu) & 0,2 & 5 \\
\hline $\operatorname{Demir}(\mathrm{Fe})$ & 5 & 20 \\
\hline Kurşun (Pb) & 5 & 10 \\
\hline Manganez (Mn) & 0,2 & 10 \\
\hline Nikel (Ni) & 0,2 & 2 \\
\hline Çinko (Zn) & 2 & 10 \\
\hline
\end{tabular}

Çizelge 4. Kıta içi su kaynaklarının sınıflarına göre kalite kriteri (Anonim, 2015)

Kıtaiçi Su Kaynaklarının Sınıflarına Göre Kalite Kriterleri

\begin{tabular}{|c|c|c|c|c|}
\hline \multicolumn{5}{|c|}{ Su Kalite Sınıfları } \\
\hline Su Kalite Parametreleri & $\mathrm{I}$ & II & III & IV \\
\hline \multicolumn{5}{|c|}{ İnorganik kirlenme parametreleri ${ }^{a}$} \\
\hline Arsenik (As) $(\mu \mathrm{g} / \mathrm{l})$ & $\leq 20$ & 50 & 100 & $>100$ \\
\hline Bakır $(\mathrm{Cu})(\mu \mathrm{g} / \mathrm{l})$ & $\leq 20$ & 50 & 200 & $>200$ \\
\hline Baryum $(\mathrm{Ba})(\mu \mathrm{g} / \mathrm{l})$ & $\leq 1000$ & 2000 & 2000 & $>2000$ \\
\hline Civa $(\mathrm{Hg})(\mu \mathrm{g} / \mathrm{l})$ & $\leq 0,1$ & 0,5 & 2 & $>2$ \\
\hline Çinko $(\mathrm{Zn})(\mu \mathrm{g} / \mathrm{l})$ & $\leq 200$ & 500 & 2000 & $>2000$ \\
\hline $\operatorname{Demir}(\mathrm{Fe})(\mu \mathrm{g} / \mathrm{l})$ & $\leq 300$ & 1000 & 5000 & $>5000$ \\
\hline Kadmiyum (Cd) $(\mu \mathrm{g} / \mathrm{l})$ & $\leq 2$ & 5 & 7 & $>7$ \\
\hline Kobalt $(\mathrm{Co})(\mu \mathrm{g} / \mathrm{l})$ & $\leq 10$ & 20 & 200 & $>200$ \\
\hline Krom (toplam Cr) $(\mu \mathrm{g} / \mathrm{l})$ & $\leq 20$ & 50 & 200 & $>200$ \\
\hline Kurşun $(\mathrm{Pb})(\mu \mathrm{g} / \mathrm{l})$ & $\leq 10$ & 20 & 50 & $>50$ \\
\hline Mangan $(\mathrm{Mn})(\mu \mathrm{g} / \mathrm{l})$ & $\leq 100$ & 500 & 3000 & $>3000$ \\
\hline Nikel $(\mathrm{Ni})(\mu \mathrm{g} / \mathrm{l})$ & $\leq 20$ & 50 & 200 & $>200$ \\
\hline
\end{tabular}

(a) Bu gruptaki kriterler parametreleri oluşturan kimyasal türlerin toplam konsantrasyonlarını vermektedir.

Su örneklerinin ağır metal içerikleri Çizelge 3'e göre değerlendirildiğinde $\mathrm{Zn}, \mathrm{Cu}, \mathrm{Cr}, \mathrm{As}, \mathrm{Cd}, \mathrm{Pb}, \mathrm{Ni}$ açısından herhangi bir sorun gözlenmemiştir. Su örneklerinin Fe analiz değerleri $587.0 \mu \mathrm{g} / \mathrm{l}$ ile $8969.7 \mu \mathrm{g} / \mathrm{l}$ arasında değiştiği ve ortalama sonucun $2769.0 \mu \mathrm{g} / \mathrm{l}$ olduğu belirlenmiştir. Çizelge 3'e göre yapılan değerlendirmede 9 ve 10 nolu örnek noktaları ortalama değerlerin her türlü zeminde sürekli sulama yapıldığı durumda sınır değeri olan $5000 \mu \mathrm{g} / \mathrm{l}$ 'nin üzerinde sonuç verdiği diğer istasyonlarda ise sorun olmadığı gözlenmiştir. Çizelge 4'de göre yapılan değerlendirme ise Fe içeriği açısından 1, 3, 4 nolu örneklerin II. sınıf su, 2, 5, 6, 7, 8, 11, 12, 14 ve 15 nolu örneklerin III. sınıf su, 9 ve 10 örneklerin IV. sınıf su olduğu belirlenmiştir.

Çorlu Deresinden alınan su örneklerinin Mn analiz değerleri $120.5 \mu \mathrm{g} / \mathrm{l}$ ile $329.7 \mu \mathrm{g} / \mathrm{l}$ arasında değiştiği ortalama sonucun $195.9 \mu \mathrm{g} / \mathrm{l}$ olduğu görülmüștür. Çizelge 3'e göre değerlendirildiğinde 2, 5, 6, 7, 8, 9 ve 10 nolu örneklerde ortalama değerlerin her türlü zeminde sürekli sulama yapıldığı durumda sınır değeri olan 
$200 \mu \mathrm{g} / \mathrm{l}$ 'nin üzerinde sonuç verdiği gözlenmiştir. Çizelge 4'e göre değerlendirildiğinde ise bütün örnek noktalarının Mn içeriği açısından II. sınıf su olduğu belirlenmiștir.

Çizelge 5. Su örneklerinin ağır metal içeriklerinin analiz sonuçları, $(\mu \mathrm{g} / \mathrm{l})$

\begin{tabular}{|c|c|c|c|c|c|c|c|c|c|c|c|c|}
\hline$* 1$ & $\mathrm{Fe}$ & $\mathrm{Mn}$ & $\mathrm{Zn}$ & $\mathrm{Ba}$ & $\mathrm{Cu}$ & $\mathrm{Cr}$ & $\mathrm{Ni}$ & Co & As & $\mathrm{Pb}$ & $\mathrm{Cd}$ & $\mathrm{Hg}$ \\
\hline 1. & 587 & 124 & 83.8 & 43.2 & 17.7 & 6.5 & 9.3 & 0.6 & 1.2 & 0.5 & 0.1 & 0.2 \\
\hline 2. & 1062.1 & 217.7 & 65.7 & 37.1 & 18.4 & 12.8 & 10.7 & 1.2 & 2.1 & 1.1 & 0.2 & 0.1 \\
\hline 3. & 703.6 & 147.1 & 80.6 & 87.3 & 21.5 & 37.4 & 12.7 & 7.1 & 2 & 0.3 & 0.1 & 0.1 \\
\hline 4. & 972 & 199.9 & 121.9 & 53.4 & 30.2 & 29.1 & 24.4 & 2.5 & 2.2 & 1.5 & 0.1 & 0.1 \\
\hline 5. & 1854.2 & 231.5 & 122.3 & 95.7 & 46.5 & 15.1 & 13.1 & 3.3 & 5 & 2.1 & 0.1 & $<0.0$ \\
\hline 6. & 2941 & 255.5 & 188.7 & 120.6 & 125.7 & 32.6 & 18 & 4 & 5.4 & 3.8 & 0.2 & $<0.0$ \\
\hline 7. & 1938.4 & 219.2 & 171 & 83 & 121.6 & 16.7 & 24.1 & 3.4 & 5.5 & 2.8 & 0.3 & $<0.0$ \\
\hline 8. & 4615.6 & 245.5 & 194.4 & 117.5 & 64.8 & 28.6 & 36.5 & 5.9 & 13.4 & 3.4 & 0.1 & $<0.0$ \\
\hline 9. & 8969.7 & 329.7 & 198.8 & 203.8 & 78.2 & 49.9 & 57 & 11.2 & 22.3 & 8.4 & 0.2 & $<0.0$ \\
\hline 10. & 5795.4 & 260.1 & 157 & 171.7 & 66.9 & 43.1 & 41.4 & 7 & 18.9 & 7.1 & 0.1 & $<0.0$ \\
\hline 11. & 2220.6 & 139.8 & 75.1 & 56.4 & 34.2 & 26.7 & 23 & 3.1 & 10.6 & 2.2 & 0.2 & $<0.0$ \\
\hline 12. & 1585.3 & 144 & 106.8 & 58.5 & 17.5 & 27.9 & 28 & 3.1 & 15.7 & 1.8 & 0.1 & $<0.0$ \\
\hline 13. & 1733 & 132.9 & 80.5 & 58 & 0.6 & 36.1 & 32.2 & 3.1 & 13.3 & 2.1 & 0.3 & $<0.0$ \\
\hline 14. & 2786.1 & 120.5 & 96.6 & 133.8 & 14 & 55.2 & 36.4 & 3.1 & 9.8 & 1.9 & 0.1 & $<0.0$ \\
\hline 15. & 3770.8 & 171.8 & 71 & 101 & 2.7 & 69.4 & 46.6 & 4 & 11 & 2.5 & 0.1 & $<0.0$ \\
\hline Ort. & 2769 & 195.9 & 120.9 & 94.7 & 44 & 32.5 & 27.6 & 4.2 & 9.2 & 2.8 & 0.2 & $<0.0$ \\
\hline Max. & 8969.7 & 329.7 & 198.8 & 203.8 & 125.7 & 69.4 & 57 & 11.2 & 22.3 & 8.4 & 0.3 & 0.2 \\
\hline Min. & 587 & 120.5 & 65.7 & 37.1 & 0.6 & 6.5 & 9.3 & 0.6 & 1.2 & 0.3 & 0.1 & $<0.0$ \\
\hline
\end{tabular}

*1) Örnek numaraları

Su örnekleri Çizelge 4'e göre değerlendirildiğinde; $\mathrm{Zn}, \mathrm{Cd}, \mathrm{Pb}, \mathrm{Hg}$, Ba değerlerine göre tüm örnekler I. sınıf su niteliğindedir. Cu içeriği açısından 1, 2, 12, 13, 14, ve 15 nolu örnek noktalarında I. sınıf su, 3, 4, 5 ve 11 nolu örnekler II. sınıf su, 6, 7, 8, 9 ve 10 nolu örnekler III. sınıf su olduğu belirlenmiştir. Cr içeriği açısından 1, 2, 5 ve 7 nolu örnekler I. sınıf su, 3, 4, 6, 8, 9, 10, 11, 12 ve 13 nolu örnek noktaları II. sınıf su, 14ve 15 nolu örnek noktaları III. sınıf su olduğu gözlenmiştir. Cr analiz sonucuna göre en fazla değer artışı diğer ağır metallerin aksine 15 nolu örnek noktasında gözlenmiştir. Ni değerlerine göre 1, 2, 3, 5 ve 6 nolu örnekler I. sınıf su, 4, 7, $8,10,11,12,13,14$ ve 15 nolu örnekler II. sınıf su, 9 nolu örnek ise III. sınıf su olduğu gözlenmiştir. En büyük değerin belirlendiği 9.nolu örnek ile en düşük değerin belirlendiği 1 nolu örnek arasında yaklaşık olarak 6 katı kadar artış belirlenmiştir. As içeriği 9 nolu örnek noktasında II. sınıf su, diğer noktalarda ise I. sınıf su olduğu gözlenmiştir. As açısından da en yüksek değerin $(22.3 \mu \mathrm{g} / \mathrm{l}) 9$ nolu örnek noktasında olduğu ve en düşük değerin belirlendiği 1 nolu örnek noktasının $(1.2 \mu \mathrm{g} / \mathrm{l})$ yaklaşık olarak 18.5 katı kadar yükseldiği belirlenmiştir. Co içeriği açısından 9 nolu örnek noktasının II. sınıf su, diğer noktaların ise I. sınıf su olduğu saptanmıştır.

\section{Toprak Örneklerinin Bazı Fiziksel ve Kimyasal Özelliklerinin Değerlendirilmesi}

Çorlu Deresi'nden alınan su örneklerinin dere yatağına yakın arazilerden toprak örnekleri de alınmıştır. Toprak örneklerinin özellikle derede meydana gelen kirliliğin toprak üzerindeki etkisini belirlemek açısından su örneklerinin alındığı örnek noktalarına yakın noktalardan alınmasına dikkat edilmiştir. Toprak örnekleri alınırken, kirlilik parametresinin değişkenlik gösterebileceği, fabrikaların artış gösterdiği bölge özelliklerini yansıtacak 20 örnek noktası seçilmiş ve toprak örneklerine ait bazı fiziksel ve kimyasal analizler yapılmıştır. Bu analiz sonuçları Çizelge 6'da verilmiştir.

20 örnek noktasında alınan toprak örneklerinde yapılan bazı fiziksel ve kimyasal analiz sonuçları incelendiğinde; pH 6.6-8.4 arasında olduğu ve 7 nolu örnek nötr, diğer örnekler ise hafif alkali pH sinıfındadır. 5, 9, 10, 12, 15 nolu toprak örnekleri orta tuzlu- tuzlu, 11, 13, 14 nolu örnekler ise çok tuzlu sınıfındadır. Toprak örneklerinin kireç içerikleri açısından yapılan değerlendirmesinde ise sonuçların \%1.211.3 değeri arasında değiştiği tespit edilmiş olup örneklerin genelinde orta kireçli olduğu saptanmıştır. Toprakların tekstür dağılımları ise 1 nolu örnek kumlu kil tın, 2 nolu örnek kumlu kil tın, 3, 4, 5, 9, 10, 11, 12, 14, 16 ve 17 nolu topraklar kil tın, 6,13, 18, 19 ve 20 nolu topraklar kil tekstür sınıfındadır. 


\begin{tabular}{|c|c|c|c|c|c|c|c|}
\hline \multirow[t]{2}{*}{ İstasyonlar } & \multirow[t]{2}{*}{$\mathrm{pH}(1 / 2.5)$} & \multirow[t]{2}{*}{$\mathrm{EC}\left(\mathrm{mmhos} \mathrm{cm}^{-1}\right)$} & \multirow[t]{2}{*}{ Kireç (\%) } & \multicolumn{3}{|c|}{ Tekstür (\%) } & \multirow[t]{2}{*}{ Tekstür Sınıfi } \\
\hline & & & & Kum & Silt & Kil & \\
\hline 1. & 8.4 & 1.62 & 2.3 & 62.0 & 22.5 & 15.5 & Kumlu Tin \\
\hline 2. & 8.3 & 1.92 & 3.5 & 48.0 & 26.5 & 25.5 & $\begin{array}{r}\text { Kumlu Kil } \\
\text { Tun }\end{array}$ \\
\hline 3. & 8.0 & 0.02 & 11.3 & 35.5 & 33.5 & 31.0 & Kil Tin \\
\hline 4. & 8.1 & 4.60 & 4.9 & 29.0 & 34.5 & 36.5 & Kil Tin \\
\hline 5. & 7.9 & 8.99 & 2.3 & 44.5 & 26.0 & 29.5 & Kil Tin \\
\hline 6. & 8.2 & 1.52 & 2.0 & 26.5 & 32.5 & 41.0 & Kil \\
\hline 7. & 6.6 & 1.64 & 2.3 & 44.0 & 32.5 & 23.5 & Tin \\
\hline 8. & 7.7 & 2.62 & 2.0 & 45.0 & 31.0 & 24.0 & Tin \\
\hline 9. & 7.8 & 5.37 & 2.5 & 27.0 & 38.5 & 34.5 & Kil Tın \\
\hline 10. & 7.8 & 6.33 & 3.1 & 31.5 & 31.0 & 37.5 & Kil Tin \\
\hline 11. & 7.8 & 11.94 & 3.0 & 48.0 & 21.5 & 30.5 & Kil Tin \\
\hline 12. & 7.8 & 9.00 & 2.8 & 43.0 & 24.5 & 32.5 & Kil Tın \\
\hline 13. & 7.7 & 10.76 & 3.0 & 38.5 & 20.5 & 41.0 & Kil \\
\hline 14. & 7.7 & 9.57 & 2.0 & 38.5 & 31.0 & 30.5 & Kil Tın \\
\hline 15. & 7.7 & 7.10 & 1.8 & 51.0 & 25.5 & 23.5 & Tin \\
\hline 16. & 8.1 & 2.35 & 1.3 & 47.0 & 20.5 & 32.5 & Kil Tin \\
\hline 17. & 7.8 & 2.01 & 3.2 & 37.0 & 28.5 & 34.5 & Kil Tin \\
\hline 18. & 8.4 & 0.02 & 1.3 & 33.0 & 20.5 & 46.5 & Kil \\
\hline 19. & 8.3 & 0.01 & 1.2 & 26.5 & 31.0 & 42.5 & Kil \\
\hline 20. & 8.1 & 1.87 & 3.0 & 19.5 & 39.5 & 41.0 & Kil \\
\hline Ortalama & 7.9 & 4.46 & 2.9 & & & & \\
\hline Maksimum & 8.4 & 11.94 & 11.3 & & & & \\
\hline Minimum & 6.6 & 0.01 & 1.2 & & & & \\
\hline
\end{tabular}

\section{Toprakta ekstrakte edilebilir bazı metallerin içeriklerinin değerlendirilmesi}

Toprakların ağır metal analiz sonuçları Çizelge 7'de verilen topraktaki ağır metal sınır değerlerine (Anonim 2005) ve Çizelge 8'de verilen Kirlenmiş Toprakta Arıtma Sonucu Uyulması Gereken Sınır Değerlerine (Anonim 2005) göre değerlendirilmiştir. Toprak örneklerinde analizi yapılan ağır metal ve kirletici metallerin analiz sonuçları Çizelge 9'da verilmiştir.

Çizelge 7. Topraktaki Ağır Metal Sınır Değerleri (Anonim 2005)

\begin{tabular}{|c|c|c|}
\hline $\begin{array}{l}\text { Ağır Metal } \\
\text { (Toplam) }\end{array}$ & $\begin{array}{c}\text { pH 5- } 6 \\
\text { Firın Kuru Toprak (mg/kg) }\end{array}$ & $\begin{array}{c}\mathrm{pH}>6 \\
\text { Firın Kuru Toprak (mg/kg) }\end{array}$ \\
\hline Kurşun & $50^{* *}$ & $300^{* *}$ \\
\hline Kadmiyum & $1 * *$ & $3 * *$ \\
\hline Krom & 100 ** & 100 ** \\
\hline Bakır* & $50 * *$ & $140 * *$ \\
\hline Nikel* & $30 * *$ & $75^{* *}$ \\
\hline Çinko * & $150 * *$ & $300 * *$ \\
\hline Civa & $1^{* *}$ & $1,5^{* *}$ \\
\hline
\end{tabular}

*pH değeri 7'den büyük ise çevre ve insan sağlığına özellikle yeraltı suyuna zararlı olmadığı durumlarda Bakanlık sınır değerleri \% 50'ye kadar artırabilir.

**Yem bitkileri yetiştirilen alanlarda çevre ve insan sağlı̆̆ına zararlı olmadığı bilimsel çalışmalarla kanıtlandı̆̆ı durumlarda, bu sınır değerlerin aşılmasına izin verilebilir.

Toprakların $\mathrm{Zn}, \mathrm{Cu}, \mathrm{Cr}, \mathrm{Ni}, \mathrm{Pb}, \mathrm{Cd}, \mathrm{Hg}$ ağır metal analiz sonuçları Çizelge 7'nin pH'nın 6'dan büyük olduğu sınır değerlere göre değerlendirilmiş ve tüm örnekler izin verilen sınır değerlerin altında olduğu belirlenmiştir. Ba, Co, Sn, As ağır metalleri ise Çizelge 8'e göre değerlendirilmiştir. Co, Sn ve As izin verilen sınır değerlerin altında iken Ba 15 nolu örnek hariç hepsinde sınır değerin üstündedir.

Çizelge 8. Kirlenmiş Toprakta Arıtma Sonucu Uyulması Gereken Sınır Değerleri (Anonim 2005)

\begin{tabular}{l|l}
\hline Kirlilik Parametreleri & Sinır Değerleri ( mg/kg Firın Kuru Toprak) \\
\hline Kobalt & 20 \\
Arsenik & 20 \\
Molibden & 10 \\
Kalay & 20 \\
Baryum & 200 \\
\hline
\end{tabular}


Çizelge 9. Ekstrakte edilebilir bazı ağır metal ve kirletici metallerin analiz sonuçları (mg/kg)

\begin{tabular}{|c|c|c|c|c|c|c|c|c|c|c|c|}
\hline İstasyonlar & $\mathrm{Zn}$ & $\mathrm{Cu}$ & $\mathrm{Cr}$ & $\mathrm{Ni}$ & $\mathrm{Pb}$ & $\mathrm{Cd}$ & $\mathrm{Hg}$ & $\mathrm{Ba}$ & Co & Sn & As \\
\hline 1. & 8 & 3 & 9 & 4.5 & 16.3 & 0 & 0.1 & 241.3 & 2.4 & 0.3 & 0.7 \\
\hline 2. & 24 & 8 & 24 & 9.3 & 18.8 & 0.1 & 0.2 & 270.4 & 3.7 & 0.7 & 2.1 \\
\hline 3. & 42 & 20 & 40.1 & 28.8 & 14.8 & 0.1 & 0.2 & 201 & 8.1 & 1.2 & 2 \\
\hline 4. & 31 & 9 & 25.1 & 10.8 & 17.8 & 0.1 & 0.2 & 232.3 & 4.6 & 1 & 1.7 \\
\hline 5. & 26 & 7 & 16.1 & 5.7 & 19.6 & 0.1 & 0.2 & 289.1 & 2.7 & 1 & 1.1 \\
\hline 6. & 21 & 6 & 21.8 & 7.5 & 20 & 0.1 & 0.2 & 281.9 & 3.1 & 0.7 & 1.1 \\
\hline 7. & 14 & 5 & 15.6 & 4.8 & 22.4 & 0.1 & 0.2 & 289.1 & 3.4 & 0.7 & 1.4 \\
\hline 8. & 34 & 10 & 14.6 & 5.4 & 21.2 & 0.1 & 0.2 & 306.4 & 2.2 & 1 & 1.1 \\
\hline 9. & 28 & 9 & 19.4 & 7.7 & 18 & 0.1 & 0.2 & 247.5 & 2.5 & 0.9 & 1.2 \\
\hline 10. & 46 & 14 & 37.9 & 14.3 & 24.4 & 0.1 & 0.2 & 355 & 5.4 & 2.5 & 3 \\
\hline 11. & 44 & 11 & 28.1 & 10.3 & 21.6 & 0.1 & 0.2 & 310.7 & 4.1 & 1.6 & 2.3 \\
\hline 12. & 53 & 15 & 37.3 & 15.1 & 20.9 & 0.1 & 0.3 & 283.3 & 5.7 & 2 & 2.7 \\
\hline 13. & 44 & 12 & 38.4 & 10.5 & 21.6 & 0.1 & 0.3 & 273 & 4.3 & 1.8 & 2.3 \\
\hline 14. & 26 & 8 & 47.9 & 7.9 & 17.8 & 0.1 & 0.1 & 294 & 2.7 & 1.1 & 1.1 \\
\hline 15. & 17 & 4 & 200.9 & 4.1 & 18.3 & 0 & 0.1 & 332.6 & 1.8 & 0.7 & 0.7 \\
\hline 16. & 9 & 3 & 16.7 & 4.9 & 20.7 & 0 & 0.1 & 318.9 & 2.6 & 0.4 & 1.1 \\
\hline 17. & 8 & 3 & 15.3 & 4.1 & 20.2 & 0 & 0.1 & 272.6 & 2.5 & 0.4 & 0.9 \\
\hline 18. & 7 & 3 & 14.7 & 4.1 & 16.5 & 0 & 0.1 & 250.7 & 2.4 & 0.3 & 0.8 \\
\hline 19. & 8 & 3 & 13.9 & 4.1 & 23.2 & 0 & 0.1 & 389.7 & 2.3 & 0.5 & 1 \\
\hline 20. & 18 & 7 & 45.6 & 19 & 15.1 & 0.1 & 0.1 & 135.5 & 5.8 & 0.5 & 1.9 \\
\hline Ortalama & 25 & 8 & 34.1 & 9.1 & 19.5 & 0.1 & 0.2 & 278.75 & 3.615 & 0.965 & 1.51 \\
\hline Maksimum & 53 & 20 & 200.9 & 28.8 & 24.4 & 0.1 & 0.3 & 389.7 & 8.1 & 2.5 & 3 \\
\hline Minimum & 7 & 3 & 9 & 4.1 & 14.8 & 0 & 0.1 & 135.5 & 1.8 & 0.3 & 0.7 \\
\hline
\end{tabular}

\section{Su ve Toprak Örneklerinin istatistiksel Değerlendirilmesi}

$\mathrm{Su}$ örneklerine ait korelasyon değerlendirilmesi Çizelge 10'da, toprak örneklerine ait korelasyon değerlendirilmesi Çizelge 11'de verilmiştir.

Çizelge 10'da verilen su örneklerinin ağır metal içeriklerine ilişkin korelasyon değerleri incelendiğinde; Fe ile $\mathrm{Mn}, \mathrm{Zn}, \mathrm{Ba}, \mathrm{Ni}, \mathrm{Co}, \mathrm{As}$ ve $\mathrm{Pb}$ arasında 0.01düzeyinde, $\mathrm{Cr}$ ise 0.05 düzeyinde önemlilik belirlenmiştir. $\mathrm{Mn}$ ile $\mathrm{Zn}, \mathrm{Ba}, \mathrm{Cu}$ ve $\mathrm{Pb}$ arasındaki ilişki 0.01 düzeyinde, Co ise 0.05 düzeyinde önemlidir. $\mathrm{Zn}$ ile $\mathrm{Ba}, \mathrm{Cu}$ ve $\mathrm{Pb}$ arasındaki ilişki 0.01 düzeyinde, Co ise 0.05 düzeyinde önemli bulunmuştur. $\mathrm{Ba}$ ile $\mathrm{Ni}$, Co, $\mathrm{As}$ ve $\mathrm{Pb}$ arasındaki ilişki 0.01 düzeyinde, $\mathrm{Cr}$ ise 0.05 düzeyinde önemlidir. Ayrıca, $\mathrm{Cu}$ ile $\mathrm{Pb}$ arasındaki ilişki 0.05 düzeyinde önemlidir. $\mathrm{Cr}$ ile Ni arasındaki ilişki 0.01 düzeyinde, As ise 0.05 düzeyinde önemlidir. Ni ile Co, As ve $\mathrm{Pb}$ arasındaki ilişki 0.01 düzeyinde, $\mathrm{Hg}$ ise 0.05 düzeyinde önemli olmuştur. Co ile As ve $\mathrm{Pb}$ arasındaki ilişki 0.01 düzeyinde önemlilik göstermiştir. As ile $\mathrm{Pb}$ ve $\mathrm{Hg}$ arasındaki ilişki 0.01 düzeyinde önemli olarak bulunmuştur.

Çizelge 10. Su Örneklerinin Ağır Metal Korelasyon Değerleri

\begin{tabular}{|c|c|c|c|c|c|c|c|c|c|c|c|c|c|}
\hline & $\mathrm{Fe}$ & $\mathrm{Mn}$ & $\mathrm{Zn}$ & $\mathrm{Ba}$ & $\mathrm{Cu}$ & $\mathrm{Cr}$ & $\mathrm{Ni}$ & Co & $\mathrm{Sn}$ & As & $\mathrm{Pb}$ & $\mathrm{Cd}$ & $\mathrm{Hg}$ \\
\hline $\mathrm{Fe}$ & 1 & $.722^{* *}$ & $.643^{* *}$ & $.900^{* *}$ & .381 & $.541^{*}$ & $.845^{* *}$ & $.823^{* *}$ & .251 & $.818^{* *}$ & $.943^{* *}$ & .016 & -.509 \\
\hline $\mathrm{Mn}$ & & 1 & $.805^{* *}$ & $.664^{* *}$ & $.698^{* *}$ & .051 & .374 & $.630^{*}$ & .134 & .367 & $.789 * *$ & .123 & -.311 \\
\hline $\mathrm{Zn}$ & & & 1 & $.670^{* *}$ & $.855^{* *}$ & .025 & .383 & $.577^{*}$ & .153 & .397 & $.714^{* *}$ & .126 & -.403 \\
\hline $\mathrm{Ba}$ & & & & 1 & .455 & $.589 *$ & $.721^{* *}$ & $.837^{* *}$ & .276 & $.667^{* *}$ & $.869^{* *}$ & -.115 & -.502 \\
\hline $\mathrm{Cu}$ & & & & & 1 & -.165 & .063 & .348 & .351 & .094 & $.530^{*}$ & .359 & -.334 \\
\hline $\mathrm{Cr}$ & & & & & & 1 & $.782^{* *}$ & .507 & .001 & $.536^{*}$ & .399 & -.182 & -.478 \\
\hline $\mathrm{Ni}$ & & & & & & & 1 & $.651^{* *}$ & .118 & $.858^{* *}$ & .739 ** & .006 & $-.586^{*}$ \\
\hline Co & & & & & & & & 1 & .188 & $.652^{* *}$ & $.772^{* *}$ & -.032 & -.385 \\
\hline Sn & & & & & & & & & 1 & .232 & .373 & .097 & -.249 \\
\hline As & & & & & & & & & & 1 & $.786^{* *}$ & .061 & $-.657^{* *}$ \\
\hline $\mathrm{Pb}$ & & & & & & & & & & & 1 & .136 & -.512 \\
\hline $\mathrm{Cd}$ & & & & & & & & & & & & 1 & -.260 \\
\hline $\mathrm{Hg}$ & & & & & & & & & & & & & 1 \\
\hline
\end{tabular}

** Korelasyon 0.01 düzeyinde önemli.

* Korelasyon 0.05 düzeyinde önemli.

Toprak örneklerinin ekstrakte edilebilir bazı ağır metal ve kirletici metalleri arasındaki korelasyon değerleri incelendiğinde; $\mathrm{Fe}$ ile $\mathrm{Zn}, \mathrm{Ba}, \mathrm{Sn}, \mathrm{Pb}$ ve $\mathrm{Hg}$ arasındaki ilişki 0.01 düzeyinde, As ise 0.05 düzeyinde önemlidir. $\mathrm{Mn}$ ile Ni, Co ve As arasındaki ilişki 0.01 düzeyinde önemli olarak elde edilmiştir. $\mathrm{Zn}$ ile $\mathrm{Cu}, \mathrm{Ni}$, Co, Sn, As, Cd 
ve $\mathrm{Hg}$ arasındaki ilişki 0.01 düzeyinde ve $\mathrm{Ba}$ ile $\mathrm{Pb}$ arasındaki ilişki 0.01 düzeyinde, Ni ve Co ise 0.05 düzeyinde önemlidir. $\mathrm{Cu}$ ile $\mathrm{Ni}, \mathrm{Co}, \mathrm{Sn}, \mathrm{As} \mathrm{Cd}$ ve $\mathrm{Hg}$ arasındaki ilișki 0.05 düzeyinde önemli bulunmuștur. $\mathrm{Ni}$ ile Co ve As arasındaki ilişki 0.01 düzeyinde ve $\mathrm{Sn}$ ve $\mathrm{Cd}$ ise 0.05 düzeyinde önemlidir. Co ile As arasındaki ilişki 0.01 düzeyinde, $\mathrm{Sn}, \mathrm{Cd}$ ve $\mathrm{Hg}$ ise 0.05 düzeyinde önemlilik göstermiştir. Sn ile As, $\mathrm{Cd}$ ve $\mathrm{Hg}$ arasındaki ilişki 0.01 düzeyinde ve $\mathrm{Pb}$ arasındaki ilişki 0.01 düzeyinde önemli olmuştur. Ayrıca, As ile $\mathrm{Cd}$ ve $\mathrm{Hg} 0.01$ düzeyinde ve $\mathrm{Cd}$ ile $\mathrm{Hg}$ arasındaki ilişki 0.01 düzeyinde önemlidir.

Çizelge 11. Toprak Örneklerinin Ekstrakte Edilebilir Bazı Ağır Metal ve Kirletici Metallerin Korelasyon Değerleri

\begin{tabular}{|c|c|c|c|c|c|c|c|c|c|c|c|c|c|}
\hline & $\mathrm{Fe}$ & $\mathrm{Mn}$ & $\mathrm{Zn}$ & $\mathrm{Ba}$ & $\mathrm{Cu}$ & $\mathrm{Cr}$ & $\mathrm{Ni}$ & Co & $\mathrm{Sn}$ & As & $\mathrm{Pb}$ & $\mathrm{Cd}$ & $\mathrm{Hg}$ \\
\hline $\mathrm{Fe}$ & 1 & -.065 & $.610^{* *}$ & $.592^{* *}$ & .414 & -.090 & -.012 & .116 & $.682^{* *}$ & $.500^{*}$ & $.702^{* *}$ & .310 & $.712^{* *}$ \\
\hline $\mathrm{Mn}$ & & 1 & .267 & -.266 & .364 & -.120 & $.640^{* *}$ & $.729 * *$ & .339 & $.665^{* *}$ & .100 & .216 & .096 \\
\hline $\mathrm{Zn}$ & & & 1 & -.001 & $.916^{* *}$ & .046 & $.609 * *$ & $.637^{* *}$ & $.918^{* *}$ & $.818^{* *}$ & .222 & $.731^{* *}$ & $.813^{* *}$ \\
\hline $\mathrm{Ba}$ & & & & 1 & -.187 & .137 & $-.521 *$ & $-.465^{*}$ & .235 & -.063 & $.804^{* *}$ & -.273 & -.010 \\
\hline $\mathrm{Cu}$ & & & & & 1 & -.006 & $.827^{* *}$ & $.817^{* *}$ & $.787^{* *}$ & $.772^{* *}$ & .000 & $.694^{* *}$ & $.702^{* *}$ \\
\hline $\mathrm{Cr}$ & & & & & & 1 & .028 & -.055 & .069 & -.080 & -.147 & -.180 & -.163 \\
\hline $\mathrm{Ni}$ & & & & & & & 1 & $.963^{* *}$ & $.457^{*}$ & $.664^{* *}$ & -.340 & $.520^{*}$ & .356 \\
\hline Co & & & & & & & & 1 & $.532 *$ & $.771^{* *}$ & -.192 & $.533^{*}$ & $.456^{*}$ \\
\hline Sn & & & & & & & & & 1 & $.835^{* *}$ & $.458^{*}$ & $.595^{* *}$ & $.719^{* *}$ \\
\hline As & & & & & & & & & & 1 & .298 & $.626^{* *}$ & $.680^{* *}$ \\
\hline $\mathrm{Pb}$ & & & & & & & & & & & 1 & .066 & .338 \\
\hline $\mathrm{Cd}$ & & & & & & & & & & & & 1 & $.716^{* *}$ \\
\hline $\mathrm{Hg}$ & & & & & & & & & & & & & 1 \\
\hline
\end{tabular}

** Korelasyon 0.01 düzeyinde anlamlı.

* Korelasyon 0.05 düzeyinde anlamlı

\section{Sonuç}

Bu çalışmada Çorlu Deresi sularının ve yakın çevresindeki toprakların kirlilik düzeyini belirlemek amacıyla su ve toprak örnekleri alınmış ve çeşitli analizler yapılmıştır. Özellikle sanayi kuruluşların çevresine olan etkisini daha net ortaya koyabilmek için sanayinin yoğun olduğu bölge seçilmiştir.

Çorlu Deresinden alınan su örnekleri analiz sonuçlarına göre; dere suyunda yapılan kirlilik oluşturabilecek elementlerden $\mathrm{Fe}$ ve $\mathrm{Mn}$ dışında diğer elementlerin izin verilen değerlerin altında sonuç verdiği tespit edilmiştir. Ancak özellikle sanayi bölgelerinin yoğun olduğu 9 ve 10 nolu örnek noktalarında Fe, Mn, Zn, Ba, $\mathrm{Ni}, \mathrm{Co}, \mathrm{Sn}$ ve $\mathrm{Pb}$ değerlerinin en yüksek olduğu görülürken, nispeten sanayi kuruluşları açısından daha az olan 1 ve 2 nolu örnek noktalarında en düşük değerlerde olduğu tespit edilmiştir. Bu nedenle yasal mevzuatlarda belirtilen limitlere yakın olan değerlerinde uygun atık yönetimi prosedürü uygulanarak değerlerin daha da düşürülmesi gerekmektedir.

Toprak örneklerinde ise Baryum elementi analiz sonuçları 135.5-389.7 mg/kg olarak ölçülmüş ve izin verilen sınır değerlerinin üstünde sonuç verdiği görülmüştür. Toprakta analizi yapılan diğer elementlerin sonuçları izin verilen sınırların altında sonuç vermiştir. Fakat $\mathrm{Cr}$, $\mathrm{Ni}$ ve $\mathrm{Co}$ gibi bazı elementler yasal mevzuatta izin verilen limitlerin altında sonuç vermesine rağmen bazı örnek noktalarında nispeten yüksek değerlere ulaştığı görülmektedir. Bu denenle bu elementler açısından kirlilik düzeyi sürekli kontrol altında tutulması gerekmektedir.

Su örneklerinin ağır metal analiz sonuçlarının artış gösterdiği 9,10, 13, 14 nolu örneklerin yakın çevrelerindeki topraklarda da artış olduğu belirlenmiştir. Toprak özelliklerine baktığımızda bu durumu çevredeki çeşitli üretim yapan fabrikaların artmasının yanında, bu noktaların tekstür sınıflarıyla ve artan kil oranlarıyla ilişkili olduğu ile açıklanabilir. Yine 19 ve 20 nolu toprak örneklerinde analizi yapılan tüm ağır metal sonuçlarında artış olduğunu ve bu durumunda artan kil miktarıla ortamda tutulduğu şeklinde açıklanabilir.

Ergene havzasının iyi nitelikli ve verimli topraklarının ve bu havzayı besleyen su kaynaklarının çevre kirliliğine maruz kalmaması için Su Kirliliği Kontrolü Yönetmeliği ve Toprak Kirliliği Kontrolü Yönetmeliği' ne uygun hareket edilmesi gerekmektedir. Ayrıca ıslah çalışmalarının aksamadan devam edilmesi ve gerekli kontrollerin yapılması için özen gösterilmelidir.

\section{Kaynaklar}

Anonim, 2004b. Çevre ve Orman Bakanlığı Su Kirliliği Kontrolü Yönetmeliği (SKKY), 31.12.2004 Tarih Ve 25867 Sayılı Resmi Gazete (Değişik: RG-13.02.2008-26786).

Anonim, 1996a.TS 8335 ISO 10693 Toprak Kalitesi-Karbonat Muhtevası Tayini-Volümetrik Metot. Çevre İhtisas Grubu. Anonim, 1996b. TS 8334:1990/ TS ISO 11265. Topraklar-Toplam Tuz Miktarı Tayini. Ziraat İhtisas Grubu.

Anonim, 1996c. TS 9748 EN 27888 Su Kalitesi-Elektriksel İletkenlik Tayini. Alıcı Ortam Özel Daimi Komitesi. 
Anonim, 2003. Meriç Deltası Sulak Alanının İyileștirilmesi (Rehabilitasyonu) Üzerinde Araştırmalar. DSİ, Edirne.

Anonim, 2004a. TS ISO 14869. Soil Quality - Dissolution For The Determination Of Total Element Content - Part 1: Dissolution With Hydrofluoric And Perchloric Acids.

Anonim, 2005. Toprak Kirliliği Kontrolü Yönetmeliği, Resmi Gazete Tarihi: 08.06.2010 Resmi Gazete Sayısı: 27605. T.C Çevre Ve Orman Bakanlığından.

Anonim, 2009. TS-7739 Sulama Suyu. Ziraat İhtisas Grubu.

Anonim, 2010b. DSİ XI. Bölge Müdürlüğü.1965-1990 Arasında Lüleburgaz İstasyonunda Ölçülen Aylık Toplam Akımlar Ve Ortalama Değerler. DSİ XI. Bölge Müdürlüğü.

Anonim, 2013.TS EN ISO 10523 Su Kalitesi-pH Tayini. Çevre Teknik Komitesi.

Anonim, 2015. Yüzeysel Su Kalitesi Yönetimi Yönetmeliğinde Değişiklik Yapılmasına Dair Yönetmelik. RG:29327sayı 15 Nisan 2015 tarih

Arkoç 0, 2012. Ergene Havzası Çorlu-Çerkezköy Kesiminde Yeraltısularındaki Ağır Metal Kirliliğinin Araştırılması. 65.Türkiye Jeoloji Kurultayı, 151s, Kırklareli Üniversitesi Teknik Bilimler MYO, Kırıkkale.

Baş L, Demet Ö, 1992. Çevresel Toksikoloji Yönünden Bazı Ağır Metaller. S.Ü. Vet. Fak. Formakaloji-Taksikoloji, 5. Sayı, ABD.

Bouyoucos GS, 1951. A Recalibration of the Hydrometer Method For Making Mechanical Analysis of Soils. Argon. J. 43:434-438.

Cvetkovic J, Arpadjan S, Karadjova I, Stafilov T, 2006. Determination Of Cadmium in Wine by Electrothermal Atomic Absorption Spectrometry. Acta Pharm 56:69-77.

Eaton FM, 1950. Significance of Carbonates in Irrıgation Maters. Soil Sci.69: 123-133.

Eyupoğlu F, Kurucu N, Talaz S, 1996. Turkiye Topraklarının Bitkiye Yarayıslı Bazı Mikroelement (Fe, Cu, Zn, Mn) Bakımından Genel Durumu. Toprak Ve Gubre Arast.Enst. Gen Mud. Yayın No. 217, Ankara.

Gerendas JJ, Polacco C, Freyermuth SK, Sattelmacher B, 1999. Significance Of Nickel For Plant Growth And Metabolism. Journal Of Plant Nutrition And Soil Science, Germany, 162: 241-256.

Güneş Y, Ekmekyapar F, Yasavul E, Ordu Ş ve Karakaya N, 2001. Çorlu Deresi'ne Deşarj Olan Endüstriyel Atıkların Meydana Getirdiği Kirliliğin Belirlenmesi. Ulusal Sanayi Çevre Sempozyumu ve Sergisi, 844- 847, Çevre Müh. Bölümü Mersin.

http://www.cerkezkoy.bel.tr (erişim tarihi, 10.04.2014).

Kocaman H, Akın Y, Oğuzhan A, 2011.Trakya'da Ergene Nehri Kirliliğinin Tarım Üretimine Olan Etkisi Edirne Örneği. Karadeniz Fen Bilimleri Dergisi, 2:104-105.

Metz W, 1987. Chromium. Trace Elements in Human and Animal. Academic Pres, Richard Anderson, Maryland, Volume 1:258-260s.

Richards LA, 1954. Diagnosis and improvement of saline and alkali soils. USD A Handbook No: 60.

Sağlam MT, 2008. Toprak ve Suyun Kimyasal Analiz Yöntemleri. Namık Kemal Üniversitesi, Yayın No: 2, Tekirdağ.

Tan A, 2006. Atık Sularda Bazı Kirlilik Parametrelerinin İncelenmesi. Yüksek Lisans, T.C. Trakya Üniversitesi Fen Bilimleri Enstitüsü, Anorganik Kimya Anabilim Dalı, Edirne.

Yurtseven N, 1984. Deneysel İstatistik Metotları. Köy Hizmetleri Genel Müdürlüğü Yayınları No:56, Ankara. 